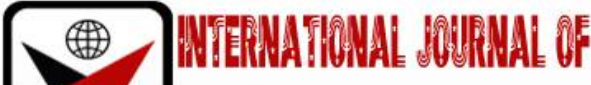

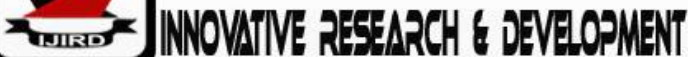

ISSN 2278 - 0211 (Online)

\section{Atmospheric Gases: Human Impact and Its Environmental Implications}

\author{
Oyelami Ayobami Alani \\ Chief Lecturer, Department of Geography, School of Arts and Social Sciences, \\ Emmanuel Alayande College of Education, Oyo, Oyo state, Nigeria
}

\begin{abstract}
:
The paper examines how man influences the composition and biospheric functioning of Atmospheric gases. Related literatures and secondary data were used to give explanations on issues. Atmospheric gases were studied with respect to their physical properties, specific human uses, reactivity among gases and their environmental consequences. Major challenge facing the biospheric environment arose because man is increasing the volume of atmospheric gases more than proportionately unfortunately these anthropogenic gases possess powerful greenhouse effect and very long atmospheric lifetime. Among the suggestions made are; (1) clear scientific explanation is needed to determine (a) the relative contribution of nitrous oxide to Atmospheric disorder, (b) the extent at which anthropogenic gases are influencing gaseous reactivity in the Atmosphere. (2) Ban on the generation of dangerous gases supposes to be made worldwide. (3) Emission of dangerous anthropogenic gases can be controlled through chemical reaction to a friendly gaseous form (4) Environmental education is important along the less privileged societies of the world (5) Developing nations should learn to tap Atmospheric resources for developmental purposes.
\end{abstract}

Keywords: Atmospheric gases, man, environment

\section{Introduction}

The atmosphere is used to describe theair that envelops the land and water components of the Earth. And Atmospheric gases are gases located in the Earth's Atmosphere (Resource Center 2017).It is one of the three realms that interacted to produce the biosphere. According to ACA (2019), various regions of the Earth atmosphere are named using different classification schemes. Four of these are; temperature,ionization, gravitation, andcomposition. In term of temperature, the troposphere $(0-17 \mathrm{~km})$ is where the surface weather occurs. Temperature decreases with altitude along the zone. The stratosphere $(17-48 \mathrm{~km})$ contains the ozone layer, and so the temperature is slightly high. The Mesosphere (48-80 km) is the coldest part of the atmosphere. Temperature rises rapidly in the Thermosphere/Ionosphere (80-300 $\mathrm{km})$.

Most of the atmosphere's air molecules are held close to the earth's surface by the force of gravity. Gravity manages to overcome the thermal motion of the air molecules within 600 kilometres from the land surface and as a consequence these gases are retained by the Earth Atmosphere. Above 600 kilometres, air molecules have enough energy above the Earths escape velocity (gravitational pull) of 11 kilometres per second (Oxford 2019).

Atmospheric pressure decreases with increasing altitude.More than half of the air molecules are located below the altitude of 5.5 kilometres. Atmospheric pressure decreases regularly from $1000 \mathrm{mb}$ at sea level, $500 \mathrm{mb}$ within the lowest 5.5 kilometres, $100 \mathrm{mb}$ at 12 kilometres, and $1 \mathrm{mb}$ at 50 kilometres. The molecules are far apart at higher altitude because there is less pressure (gravity) to 'push' them together (Pidwiray 2006,Scott 2018, andBroacker 2019).

Differences in air pressure equally make it possible to classify the Atmosphere in term of Homosphere and Heterosphere. Below an altitude of 100 kilometres, the Earth Atmosphere is relatively uniform in composition and is called the Homosphere. Above 100 kilometres, individual gases are separated and the zone is called the heterosphere (Engineering Toolbox 2019, Physical Geography 2019).Atmosphere start to become ionised (electrically charged) above about 70 kilometres and attained a maximum ion concentration at 300 kilometres (ACA2019).

Generallythe atmosphere is composed of four main classes of properties. These are electromagnetic waves,gases, water vapour, and particulate matter. This paper focuses entirely on atmospheric gases and not the other components.The paper is essentially explanatory in approach and it rests heavily on the synthesis ofestablished facts and secondary data. 


\section{Physical Attributes of the Major Atmospheric Gases}

\begin{tabular}{|c|c|c|c|c|}
\hline $\mathbf{S} / \mathbf{N}$ & $\begin{array}{l}\text { Atmospheric } \\
\text { Gases }\end{array}$ & $\begin{array}{l}\text { Atmospheric } \\
\text { Volume (\%) }\end{array}$ & $\begin{array}{c}\text { Molecular } \\
\text { Atomic } \\
\text { Weight }\end{array}$ & Atmospheric Peculiarity \\
\hline 1. & Nitrogen $\left(\mathrm{N}_{2}\right)$ & $78.000,000,000$ & 14.0067 & Indirectly Reactive, Soil fertility \\
\hline 2. & Oxygen $\left(\mathrm{O}_{2}\right)$ & $20.440,000,000$ & 15.994 & $\begin{array}{c}\text { Respiration/Reactive/Global } \\
\text { Cooling. }\end{array}$ \\
\hline 3. & $\operatorname{Argon}(\mathrm{Ar})$ & $00.930,000,000$ & 39.95 & Inert \\
\hline 4. & $\begin{array}{c}\text { Carbon } \\
\text { Dioxide }\left(\mathrm{CO}_{2}\right)\end{array}$ & $\begin{array}{c}00.360,000,000- \\
00.410,000,000\end{array}$ & 44.00 & Respiration/Greenhouse/Reactive \\
\hline 5. & Neon $(\mathrm{Ne})$ & $00.001,818,000$ & 20.18 & Inert \\
\hline 6. & Helium (He) & $00.000,524,000$ & 4.002602 & Inert/Universe gas \\
\hline 7. & Methane $\left(\mathrm{CH}_{4}\right)$ & $\begin{array}{c}00.000,179,000- \\
00.000,187,000\end{array}$ & 16.043 & $\begin{array}{l}\text { Greenhouse/Ozone } \\
\text { depletion/Reactive }\end{array}$ \\
\hline 8. & Krypton & $00.000,114,000$ & 83.80 & Chemically Inert \\
\hline 9. & $\begin{array}{c}\text { Nitrous } \\
\text { Oxide }\left(\mathrm{N}_{2} \mathrm{O}\right)\end{array}$ & $00.000,030,000$ & 44.02 & $\begin{array}{c}\text { Greenhouse / Reactive/ } \\
\text { Ozone depletion }\end{array}$ \\
\hline 10. & Xenon & $00.000,009000$ & 131.31 & Inert \\
\hline 11. & $\begin{array}{c}\text { Ozone }\left(\mathrm{O}_{3}\right) \\
\text { (Troposphere) }\end{array}$ & $\begin{array}{c}00.000,004,000- \\
00.000,000,100 \\
\end{array}$ & 48.00 & $\begin{array}{c}\text { Greenhouse/Reactive/Ozone } \\
\text { depletion } \\
\end{array}$ \\
\hline 12. & Hydrogen $\left(\mathrm{H}_{2}\right)$ & $00.000,000,000,500$ & 02.016 & Universe gas/ Reactive \\
\hline 13. & $\begin{array}{c}\text { Sulphur } \\
\text { Dioxide }\left(\mathrm{SO}_{2}\right)\end{array}$ & $00.000,000,100$ & 64.006 & Reactive/Global Cooling \\
\hline 14. & Iodine $\left(\mathrm{I}_{2}\right)$ & $00.000,000,100$ & 126.90 & Halogen/Reactive \\
\hline 15. & $\begin{array}{l}\text { Oxides of } \\
\text { Nitrogen }\end{array}$ & $00.000,000,001$ & 30.00 & Pollutant/ Reactive \\
\hline 16. & $\begin{array}{c}\text { Ammonia } \\
\left(\mathrm{NH}_{4}\right)\end{array}$ & $00.000,000,001$ & 17.031 & Reactive/Pollutant \\
\hline 17. & Radon (Rn) & Trace. & 222.01758 & Inert/ Pollutant \\
\hline 18. & $\begin{array}{l}\text { Carbon } \\
\text { Monoxide }\end{array}$ & $00.000,000,100$ & 28.010 & Reactive/Pollutant \\
\hline
\end{tabular}

Table 1: Showing the Physical Peculiarities of Major Atmospheric Gases

Compiled from various sources

Atmospheric gases vary in terms of volume, atomic weight, reactivity, biospheric function, sources, reservoirs, and circulatory system. With regard to atomic weight of gases for instance, the average is 28.9647 grams per mole. As such, if the molar mass of a given gas is less than 28.9647 grams per mole, it is lighter than air, and if it exceeds this value, the given gas is heavier than air (Engineering Toolbox 2019). Gases like radon, xenon and iodine possess heavy molecular weight while hydrogen and helium are very light in weight.Nitrogen and oxygen are found in abundance, argon and carbon dioxide are in minute proportions while all the remainder are in trace amounts.The summary is on Table1.

The first is Nitrogen gas. Majority of Earth's atmosphere is made upof 78 percent Nitrogen gas by volume. The atmosphere acts as reservoir (sink) for Nitrogen, but it is also stored in ocean water, watershed (sediment/soil), and plant matters. Nitrogen does not react with materials' that makes up the solid earth, it is very stable in the presence of solar radiation, and is not involved to a great extent in chemical reactions that occur in the atmosphere (inert).Thus over geological time, it has built up in the atmosphere to a much greater extent than other gases(UNC 1999, Widdison 2017, Periodic Table 2019).Living things have evolved breathing 20.4 percent oxygen from atmosphere and if the volume of oxygen was higher, one would find many items all too ready to burst into flames. Nitrogen dilutes the oxygen to a concentration which isnormal for life to develop (Jack2018,Crean2018, Tezel 2018, Marne 2016, Stevens et al 2018, Arthur 2003, Harrison 2019).

The next most abundant gas in the Atmosphere is Oxygen $\left(\mathrm{O}_{2}\right)$.It is an active, life-sustaining component of the atmosphere that makes up 20.44 percent by volume and 23 percent by weight of air.It is produced byphytoplankton, trees, shrubs and grasses through photosynthesis. It is dissolved in water bodies and very strongly bound with other compounds such as silicates and oxides. Oxygen is highly oxidizing, it accepts electron from other substances during reaction and forms compound with virtually all chemical elements (air, water, and land) except the noble gases. It reacted with rocks and effectively rusted the planet.The rusting process allowed many of oxides in minerals to form and the rusting stopped because the chemical reactions over several geological ages had got reduced and this allows the oxygen levels of today to grow to significant level in the atmosphere ((Sheardown et al 2019, Waverly 2018, Sarahzielinski 2019, Roach 2019).

By mass, oxygen is the third most abundant element in the universe, after hydrogen and helium. The relative abundance of oxygenover the entire earth is about 10,000 times more than nitrogen. This is because oxygen is a major component of the solid earth while nitrogen is not incorporated into the solid earth(Broecker2019, Scott 2018).

Argon constitutes $0.934 \%$ by volume. It is relatively heavy and tends not to driftinto the outer space. The gas dissipates rapidly in well ventilated areas. It isthe most abundant of the noble gases in the earth's atmosphere because, 
like other noble gases, it is stable and resists combining with other elements (chemically inert). Once it get to the atmosphere, it is difficult to get rid of.Relatively a greater volume of Argon is emitted from the Earth's mantle and it is found occluded in the Earth's crust and ocean waters (The Weather Prediction 2019,Pappas 2019,Duncan 2018, Lenntech 2017, Lenntech 2019, Encyclopedia Britannia 2019).

.The forth most abundant gas in the Earth's atmosphere is Carbon dioxide. Carbon dioxide is the primary carbon source of life on earth and its concentration is been regulated by photosynthetic organisms and geological events. Plant, algae and bacteria use light to photosynthesize carbohydrate from carbon dioxide and water resulting in the emission of oxygen as waste product. Carbon dioxide is returned to water through the gills of fish and to air via the lungs of land animals. The most important natural sources include; volcanoes, hot springs and geysers, sedimentary rocks, the oceans, detritus (wastes) and biota (plant and animal). In terrestrial environment, forests and peat deposits are the highest carbon reservoirs.Other natural sources includevolcanoes, hot springs, ground water and glaciers.It plays a significant role in the processes of photosynthesis and greenhouse functions(Nukurangi 2012, Boden et al 2017, Plass 2008, Encyclopedia Britannica 2019).

The fifth Atmospheric gas by volume is Neon. It is non-toxic gas which occurs in minute (trace)quantity. It accounts for 18 part per million of the volume of the atmosphere.Neon is about 3.5 times as plentiful as helium in the atmosphere. It is chemically unreactive (inert), and form no compound with other gases.The gas is believed to have originated fromrocks of the Earth's crust (Lenntech 2019, Encyclopedia Britannica 2019,Encyclopaedia Britonnica 2017).

The next atmospheric gas is Helium.Earth atmosphere contain only about 5 parts per million of helium.It is the second most abundant element in the universe, but on earth it is rather rare.It is the least reactive member of a special group of gases known as the 'noble' or 'inert' gases. It does not burn, lighter than air and less water soluble than other gases.It is produced as a product of the fusion reaction inside stars such as the sun and from the decaying radioactive elements inside the earth (uranium radon and thorium). Helium occurs naturally in the Earth's crust, where it is trapped in non- porous rock pockets. It is mined like oil (Garden 2019, Pappas 2019, Periodic Table 2019).

Methane (CH4) is ahydrocarbon; it is formed by both geological and biological processes. Biological sources include; natural decomposition of plant and animal matter in airless (anaerobic) conditions (mashes, rice paddies, and the gut of animals), and throughmethane-oxidizing bacteria. Geological sources are; reservoir under sea floor (seepage vents that are rich in organic sediments), volcanic eruptions, and polar permafrost.The primary natural sink for methane is the atmosphere and soil(Drbogman 2019, EPA 2019,Heilig 1994, Editors of Encyclopaedia 2019).

Krypton (hidden) gas is the next. It is one of the rare gases on earth, composing of only 1 part per million of the atmospheres by volume. Krypton is chemically inert, and it is 2.8 times as dense as air. Krypton is considered to be nonmetal and nontoxic. The most important source of krypton is the Earth atmosphere.Earth has retained all the noble gases that were present at its formation except helium (Periodic Table 2019, Encyclopedia Britannica 2019, Steward 2019). Nitrous oxide has been found in the atmosphere for millions of years. Microbial processes of Nitrogennitrification and denitrification, Oceans, and Atmosphere are the natural sources(Tian et al 2018, Grossman 2019,Grace and Barton 2019).

Xenon is a rare atmospheric nontoxic and chemically inert gas. It is a trace gas in the Earth's atmosphere and occurs in 1 part in 20 million. The name comes from a Greek word 'xenos' meaning strange. It originated as a component of gases emitted from some mineral springs and possibly the inner core (Lenntech 2019, Steward 2012, Bradford 2016).

Ozone or tri-oxygen isan inorganic molecule with the chemical formula 03, which usually breaks down in the lower atmosphere to 02 (di-oxygen).It is present in very low amount throughout the earth atmosphere, with the highest concentration high in the ozone layer of the stratosphere. Ozone gas accounts for the distinctive odour of the air after a thunderstorm or around electrical equipment.

Ozone is formed in the upper atmosphere when UV rays from the sun split diatomic oxygen. The lone oxygen atom then collided and reacted with other oxygen molecules to make whole called ozone. Photochemical reactions between nitrogen oxides and hydrocarbons in the lower atmosphere can equally producetroposphere ozone. Surface or low level ozone (03) can also resulted from the subsidence of stratospheric ozone from the upper atmosphere toward the Earth's surface. Itis also created indirectly by local pollutants (Editors of Encyclopaedia 2019, Lenntech 2019, Tian et al 2018).

Hydrogen is the twelfth atmospheric gasby volume. It is a nontoxic, non-metallic and highly combustible gas. Compounds containing hydrogen are water and methane (CH4). The cloud of gas and dust from which our solar system formed was dominated by hydrogen gas. Hydrogen is the most abundant element/chemical substance (75 percent) in the universe.It possessesthe highest molecular speed and diffusivity. Since hydrogen is very light in mass, gravity cannot pull it enough which make it float in outer space. Million tonnes of hydrogen are not affected by the earth gravityand this allows it to escape into the outer spacedaily.This is whythere is less than one part per million of hydrogen gas in the earth's atmosphere. (Lenntech 1998, SkyRobin 2019, Quora 2019, Tian et al 2018).

Sulphur dioxide is a naturally occurring chemical compound whichgets into the atmosphere through natural processes like volcanic eruption, forest fires, phytoplankton's bye products, and oxidation of organic materials in soil.The lifetime of sulphur dioxide molecules in the stratosphere is several weeks during which it produces sulphate aerosols.It reacts easily with other substances to form harmful compounds like sulphuric acid, sulphurous acid and sulphate particles which are the main component of acid rain.

Atmosphere Iodine is non-metallic member of the halogens (fluorine, chlorine, bromine), but it is less reactive than others. Oceans are the most important source of natural iodine but it is also present in molten and soil (ATSDR 2004). Iodine in the air combine with water or particles in the air and when this particles/water falls to the ground, it entered the soil and water again.Ammonia is the most abundant alkaline gas in the atmosphere, and a major component of total reactive nitrogen. Atmospheric ammonia binds to other gases to form ammonium. It combines with sulphates and nitrates to form secondary fine particulate matter (NYSDH 2019). 
Radon isfound in igneous rocks, soil, well water and the atmosphere. It is formed when heavier radioactive elements like uranium and thorium in rocks and soil breaks down. A radioactive element is one that gives off radiation and breaks down to form a different element.It is the heaviest of all gases, roughly eight times heavier (Lenntech 2019, Rasmussen 1986,EPA 2019).

Carbon monoxide formed from photochemical reactions in the atmosphere,and in the processes of volcanoes, and forest fires. The gas is short lived and it contributed to the formation of ground level ozone.A molecule of carbon monoxide contains one carbon and one oxygen atoms. It is equally found in gaseous nebulae and atmosphere of other planets, ice, and Comet. The gas eventually reacts with oxygen to form carbon dioxide(UCSE 2007, SEPA 2019).

\section{Human Significance of the Major Atmospheric Gases}

Man has learnt to liquefy, solidified and use all the Atmospheric gases over three centuries ago, and this allowed for several scientific, technological and industrial breakthroughs which had transformed the human landscapesof today significantly.

Nitrogen as a gas for instance, was first discovered in 1772 by Daniel Rutherford, and got liquefied at the Jagellonian University in 1883 . The gas becomes liquid at $-195.79^{\circ} \mathrm{C}$ and becomes solid at $-210^{\circ} \mathrm{c}(\mathrm{CLNT} 2019)$.Today, manmade Nitrogen accounted for over half of the world demand. This increased from 15 percent in 1850 to 60 percent in 2005, as a response to global demand for food (fertilizer) and industrial technology (coolant for computers, chemical to remove unwanted skin warts and pre-cancerous cells, nitric acid, nylon, dyes, explosives), among others(Royal Society of Chemistry 2019 , BBC news 2012, Universal Industrial Gases Inc. 2019).

Oxygen gas was first discovered by Swedish pharmacist called Carl Wilhelm Scheele in 1772, and by 1877it was liquefied by Lous Paul Cailletet, Raoul Pictet and Faidra Papenelopoulou.The liquid state was attained at $-182.96^{\circ} \mathrm{C}$ while it turns solid at $-218.8^{\circ} \mathrm{C}$. Common uses of oxygen include industrial ingredient (production of steel, plastics, textiles, brazing, welding and cutting of steels/metals), fuel (rocket propellant),and lifesupport system (hospital,aircraft, submarine, spaceflight and diving) (Papanelopoulou 2013, UIG 2016, Crean 2018, Roach 2004).

Fossil fuel is able to undergo combustion because of atmospheric oxygen. Lack of oxygen underwater is what make submarine hard to power (i.e. cannot burn fossil fuel without oxygen). Dirt of oxygen in space requires space missions to use other primary energy sources like radioisotope, thermal generators, hydrogen, or solar power (Broecker2019, Scott 2018).

Argon gas was suspected by Henry Cavendish in 1785, discovered by Sir William Ramsay in 1894 and got liquefied by Olszewski K, Williams Ramsay and Sydney Young in 1895. It turns liquid at -185.70 and solid at $-189.2^{\circ}$. Argon gas is used when an inert atmosphere is needed particularly in the production of titanium, protection of weld area (gas metal arc, gas tungsten arc), growing of crystals of silicon and germanium (reactive materials), and the production of incandescent light bulbs (to stop oxygen from corroding the filament) (Lenntech 2019, Livescience 2017, Encyclopedia Britannica 2019, Duncan 2019).

Carbon Dioxide gas was first identified by Joseph Black in 1750 and became liquefied by Humphry Davy and Michael Faraday in 1823 . It becomes liquid at $-37^{\circ} \mathrm{C}$ and solid at-78.5 $\mathrm{c}$.It is used in soft drink and beer to make them fizzy. Fire extinguishers use carbondioxide because it is denser/heavier than airand can blanket fire. The burning material is deprived of oxygen it needs to continue burning. Other uses include; enhancement of metal hardness, production of chemicals and refrigeration, among others (Boden et al 2017, Nukurangi 2012, Plass 2008).

Neon (New) was discovered by William Ramsay and Morris Travers in 1898 at University College, London. The gas turns liquid at $-245.92^{\circ} \mathrm{C}$ and solid at $-248.6^{\circ} \mathrm{C}$. Liquefied neon is commercially used as a cryogenic refrigerant in applications not requiring the lower temperature range attainable. It is also used in vacuum tubes, high voltage indicators, lightning arresters, wave meter tubes, television tubes, and helium-neon lasers. Neon light has the ability to penetrate through fog, in which other lights are impossible to detect; hence it forms a valuable lighting system in the extreme cold regions (Lenntech 2019, Encyclopaedia Britannica 2019).

Evidence of Helium gas was made by Jules Janssen and Norman Lockyer in 1868, while the liquidation was made by Heike Kamerlingh in 1908 .The liquid state is attained at $-268.928^{\circ} \mathrm{C}$, while the solid state is at $-272^{\circ} \mathrm{C}$. Helium is used in the treatments of asthma, bronchitis, and other lung deficiencies. It is also employed as ingredients in high speed internet and cable TV, computer hard drives,cleaning of rocket fuel tanks, airbags, and microscopes. Liquid helium can cool most metal to temperature near zero. This reduces the metals electrical resistance, so an electrical current applied to the metal will flow without stopping. This makes magnetic resonance imaging technology possible. Wide varieties of industries use helium. (Garden 2019, Pappas 2019 APCI 2019).

Methane natural gas was discovered by Allessadro Volta between 1776 and 1778, and got liquefied in 1964.It turns liquid at $-161.60^{\circ} \mathrm{C}$, and solid at $-182.5^{\circ} \mathrm{C}$. It constitutes about 87 percent of natural gas by volume and is used in the generation of electricity, the production of ammonia, petroleum refining, and food processing (hydrogenated oils such as margarine). It is also used in the manufacture of organic chemicals and biogas(USEPA 2019, Sciencing 2019, EPA 2019).

Krypton was one of the three noble gases discovered in1898 (Krypton, Xenon and Neon) by William Ramsay and Morris Travers who had earlier discovered Helium and Argon. The gas becomes liquid at $-153.22^{\circ} \mathrm{C}$ and solid at $-157.36^{\circ} \mathrm{C} . \mathrm{It}$ is used with other rare gases in fluorescent lamps-the gas is injected into some incandescent light bulbs, because it extends the life of the tungsten filament that makes those bulbs glow. And because it is such a heavy gas, it is sealed between the glasses of some double-paned windows to help them trap heat (Chemistry Explained 2019, Encyclopaedia Britannica 2019, Periodic Table 2019).

When exposed to an electrical current under low pressure, krypton gas lights up like neon but instead of red orange, krypton glows smoky white. Although it is extremely un-reactive, krypton is now found to be reactive with 
fluorine. Krypton is used in lightning particularly high-powered airport runway lights.Ionized krypton gas is used as a brilliant white light source in high source in high speed photography (Substance Informatiom2019, Pappas 2004, Katie 2012, Steward 2019).

Nitrogen Oxide was discovered by Joseph Priestly in 1772 . The gas turns liquid at $-88.48^{\circ} \mathrm{C}$ and solid at $-90.86^{\circ} \mathrm{C}$. It occurs through fertilizer application and, manufacture of acids, nylon, transport and power station discharges.It has anaesthetic (sedative) and analgesic (pain reliever in dentistry, childbirth, and surgery) effect. It also causes amusing effects (laughing gas). This makes it useful in medicine and dentistry, as well as dairy industry (as a mixing and foaming agent).It is used as rocket motor oxidizer, as an internal combustion engine in speed booster and aerosol spray propellant(AQFS 2019, USEPA 2019).

Xenon was one of the trace gases discovered by Williams Ramsay and Morris Travers in 1898. The gas turns liquid at $-107.1^{\circ} \mathrm{C}$ and solid at $-111.8^{\circ} \mathrm{c}($ Lenntech 2019$)$. It is used inthe production of flash lamps and the manufacture of drugs like s-fluorouracil which is used to treat cancer. It is an excellent solvent as it can dissolve hydro carbon biological molecules and water.Xenon is use in photographic flashes, in high pressure arc lamps for motion picture projection. It is also used in instrument for radiation detection. They illuminate road signs and markings better than convectional lights. Xenon is used in nuclear energy plants and for filling television and radio tubes (Bradford 2016, Steward 2019, Lenntech 2019, Chemicool2019).

Ozone gas was first discovered by Christian Friedrich Schonbein in 1838 while the ozone layer was by Charles Fabry and Henri Buissen in 1913. The liquid state is attained at $-112^{\circ}$ and the solid state at $-251.4^{\circ}$. Ozone gas is used as chemical compound in the refrigeration (Refrigerants), substance that becomes a solution by dissolving a solid liquid or gaseous solute (solvents), substance that propels something e.g. explosive that fires bullets from a fire arm and inhaled pharmaceutical aerosol (Propellants), blowing agents (foam, polymers, plastics and metals), pesticides, fire-resistant oils, detergents, among others.

Ozone gas is a biocide that can easily control odours, kill viruses and get rid of any bacteria up to 99 percent in hospitals and laboratories. Ozone permits a major penetration and cleaning effect of the detergents, used in purifying water and air, employed for pulp bleaching for chlorine free paper, among others (Lenntech 2019, Drbogman 2019, Editors of Encyclopaedia 2019).

Hydrogen gas was suspected by RobertBoyle in 1671 but was established as a discrete substance by Henry Cavendish in 1766 .The gas was liquefied by James Dewar in 1898 . The liquid and solid states are $-252.879{ }^{\circ} \mathrm{C}$ and $-259{ }^{\circ} \mathrm{C}$ respectively. The liquid hydrogen is used as a rocket fuel when combined with liquid oxygen. It is added to fats and oils through a process called hydrogenation. It is used in the study of superconductors.Hydrogen fuel cells are being looked into as a way to provide future fuel. It possesses a lot of scientific and technological potentials (Gagnon 2019,Dohrman 2017, Nay lin Tech 2018, Derment 2006,Dohrman2017).

Sulphur dioxide is widely used as food preservatives because it possesses antimicrobial properties. It is equally used as bleaching chemical, fumigant/disinfectant, pest control, used in the preparation of sulphuric acid and several industrial chemicals (Study.Com 2019). Iodine is used for cleaning surfaces and storage containers, in the preparation of skin soap and bandages, salts, inks, lubricants, batteries, among others (ATSDR 2004).Ammonia is used as a refrigerant gas, purification of water supplies, manufacture of plastics, explosives, textiles, pesticides, dyes and others chemical.Ammonia is synthetically produced for use in refrigeration, it is considered, a natural refrigerate because it occurs in natures material cycle (Mccill2019, NYSDH 2019).

Radon gas was discovered by Ernest Rutherford and Robert B Owens in 1899, but was isolated by William Ramsay and Robert Whytlaw-Gray in 1910 . The gas becomes liquid at $-61.7^{\circ} \mathrm{C}$ and solid at $-71^{\circ} \mathrm{C}$. It is used in the treatment of maladies in a radiothorium for its ionizing radiation that kills cancerous cells. It helps in detecting seismic activity, tracer for leak detection, flow rate measurements, chemical laboratory research, among others(EPA 2019, RAS 2019).

\section{Environmental Consequences Associated with the Use of Atmospheric Gases.}

Going through the peculiarities of gases in the atmosphere, they can be easily categorised into five;these are; (i) inert gases, (ii) sunlight blocking gases, (iii) pollutants, (iv) indirect harmful gases, (v) directharmful gases (see Table1). It is important to know that some gases possess two or more of these functions.Inert gases are Argon, Neon, Helium, Krypton and Xenon. These gases are regarded as noble in the sense that they do not combine with other gases, and remains virtually unchanged through ages.Generally,noble gases are of immense use to man and are not known with adverse environmental effect(Lenntech 2019, Doug Steward 2012).

Sulphur dioxide, Ammonia, Oxides of Nitrogen,Nitrogen monoxide,Carbon monoxide, and Radon are atmospheric pollutants.About 99 percent of the sulphur dioxide in air comes from human sources;it reacts with water and oxygen in the air to form fine particles (sulphate aerosols) that are acidicresulting in acid rain.Nitrogen monoxide also reacts with oxygen or tropospheric ozone to produce nitrogen dioxide, essential gas causing the formation of acid rain. Nitrogen dioxide, nitrous acid, and nitric acid are collectively known as oxides of nitrogen (Nox), they react with other chemicals in the air to form particulate matter and tropospheric ozone.Ammonia combines with sulphate and nitrate to form secondary fine particulate matter in the atmosphere. The nitrate particles make the air hazy and difficult to see through. When tropospheric ozone mixes with carbon monoxide, the result is smog(NYSDH 2019, USEPA 2017, AQFS 2019, Canada 2019).

Biospheric cooling gases are Oxygen, Sulphur dioxide and Ozone.Oxygen is not a heat trapping (greenhouse) gas but its concentration affects how much sunlight reaches the land/water surface. Sulphur dioxide converts to sulphuric acid aerosols that block incoming solar radiation in the atmosphere and as a consequence contributed to global cooling (GCI 2019, Edgar 181 2019). All pollutants also affect how much sunlight reaches the ground surface 
Indirect harmful gases. Nitrogen, Hydrogen, and Carbon monoxide are inert in the Atmosphere but changes in chemical properties when subjected to some natural processes or reacted with other chemicals/gases by man.Nitrogen for instance cannot said to be completely inert because it forms nitric oxide and nitrogen dioxide with oxygen, form ammonia with hydrogen, and form nitrogen sulphide with sulphur (Dohrmon2017, UIG 2019, RSC 2019).

In nature, bacteria in soil and oceans break down nitrogen compounds and in the process, releases nitrous oxideNitrogen gas get converted to ammonium by certain bacteria in the soil, blue/green algae in marine environment, lightening, forest fires, hot lava, among others (nitrogen fixation process).Some of the ammonium released by decomposing plants and animals is converted to nitrate $\left(\mathrm{NO}_{3}\right)$ via a process of nitrification. (v) Oxidised forms of nitrogen such as nitrate $\left(\mathrm{NO}_{3}\right)$ and nitrite $\left(\mathrm{NO}_{2}\right)$ are converted to nitrous oxide gas $\left(\mathrm{NO}_{2}\right)$ through an anaerobic process (Steven et al 2018, Grossman 2009). When any fuel is burnt, part of nitrogen in the fuel and the surrounding air gets oxidized, producing nitrous oxide(Grace 2014). Nitrous oxide is a greenhouse and ozone depletion gas.

Hydrogen combines with other elements (chemicals/gases) to form numerous compounds like water, ammonia, methane, hydrogen peroxide and hydrochloric acid. The gasfor instance reacts with tropospheric hydroxyl radicals (highly reactive), leading to the production of methane and ozone (Derwent et al 2006, Tian 2018, ELC 2018). Methane isa green house and ozone depletion gas.

Xenon, a noble gas, was equally regarded as completely inert until 1962 when Neil Barlett proved that xenon was not inert by making a fluorine derivative with it. Many compounds of xenon have now been made, principally with fluorine or oxygen. Xenon reacts with water to form xenon oxides. Other compounds been formed with xenon include trioxide, xenon hydrate, tetra fluoride and hexafluoride. Metallic xenon was also created by using massive amount of pressure. This pointed to the possibility of endangering the Atmosphere further as technology advances(GCI 2019, Edgar 181 2019).

Direct harmful gases are Carbon Dioxide, Troposphere Ozone, Methane, and Nitrous Oxide. And the effects are in terms of greenhouse effect (global warming) and ozone depletion.Greenhouse gas is any gas that has the property of absorbing infra-red radiation (heat) emitted by the Crust into the Atmosphere andgets it redirected back to the Earth surface.The greenhouse effect is used to describe the warming of Earth's surface and the air above it. Without greenhouse gases, the average temperature of Earth's surface would be about- $18^{\circ} \mathrm{C}\left(0^{\circ} \mathrm{F}\right)$ rather than the present average of $15{ }^{\circ}$. Ozone depletion is the gradual thinning of Earth's ozone layer in the upper atmosphere caused by the release of ozone depleting gases by man.

\section{Dimension of Environmental Defects Noted withHarmful Atmospheric Gases}

Environmental problems associated with atmospheric challenges arose simply because the rate at which anthropogenicgases are being released out weight what is needed for a normal and effective atmospheric system. Human interest is not on the basis of proportions, but on needs, and this hasled to a situation in which gases released into the atmosphere are those associated with human activities-- fossil and biomass fuels production, use of industrial chemicals, fertilizer application, urban waste management, among others (See table 11). Unfortunately most of the gases generated through these activities are required by the natural system in very minute quantities-carbon dioxide, methane, nitrous oxide, and ozone.

Human activities have provided 45 percent increase in the atmospheric concentration of carbon dioxide (280 ppm in 1850 to $364 \mathrm{ppm}$ in1998). This is despite the uptake of more than half of the emissions by various natural sinks involved in the carbon cycle.Currentlythe Earth atmosphere contains 388,500 parts per million of carbon dioxide, giving an increase of 108,500 after industrialization. Since 1970, Carbon dioxide emissions have increased by about 90 percent, with emission from fossil fuel combustion and industrial processes contributing about 78 percent of the total greenhouse gas emissions in 2011. Increasing carbondioxide emissions is said to be the cause of about 50-60 percent of the global warming (United Nations 2019, Blue 2019, Plass 2008, Fletcher 2019, CCES 2019).

Methane is both a powerful and short-lived greenhouse gas compared to carbon dioxide. It is the second most abundant anthropogenic greenhouse gas after carbon dioxide. Pre industrial Atmospheric level was approximately 700 parts per billion against the current 1870 parts per billion. Anthropogenic sources accounted for approximately 76 percent of total annual emissions. China, USA, Russia, India, Brazil, Indonesia, Nigeria, and Mexico are estimated to be responsible for nearly half of all human induced emissions (Editors of Encyclopedia 2019, USEPA 2016) 


\begin{tabular}{|c|c|c|c|c|c|}
\hline $\begin{array}{l}\mathbf{S} / \\
\mathbf{N}\end{array}$ & Gases & Anthropogenic sources & $\begin{array}{l}\text { Heat Trapping } \\
\text { capacity } \\
\text { (Based on } \mathrm{Co}_{2} \\
\text { standard) } \\
\end{array}$ & $\begin{array}{l}\text { Atmosphere } \\
\text { life span (yrs) }\end{array}$ & $\begin{array}{l}\text { Environmental } \\
\text { effect. }\end{array}$ \\
\hline 1. & $\begin{array}{l}\text { Carbon } \\
\text { Dioxide }\end{array}$ & $\begin{array}{c}\text { Fossil fuel combustion, } \\
\text { Deforestation, industrial processes } \\
\text { (cement production) agricultural } \\
\text { activities }\end{array}$ & 01 & 100 & Greenhouse \\
\hline 2. & Methane & $\begin{array}{l}\text { Fossil fuel combustion, anaerobic } \\
\text { decomposition (landfills, life stock } \\
\text { rearing, rice cultivation) }\end{array}$ & $28-36$ & 15 & $\begin{array}{c}\text { Greenhouse } \\
\text { Ozone depletion }\end{array}$ \\
\hline $2 b$ & $\begin{array}{l}\text { Tetrafluorom } \\
\text { ethane }\end{array}$ & $\begin{array}{l}\text { Industrial process (refrigerator } \\
\text { and aluminium production) }\end{array}$ & 6500 & 50,000 & \\
\hline $2 c$ & $\begin{array}{l}\text { Chlorodifluor } \\
\text { omethane }\end{array}$ & $\begin{array}{l}\text { Industrial process (Refrigerator, } \\
\text { propellant) }\end{array}$ & 1810 & --------------- & Green house \\
\hline $2 d$ & $\begin{array}{l}\text { Dicholrodiflu } \\
\text { oromethane }\end{array}$ & $\begin{array}{l}\text { Industrial process (Refrigerator, } \\
\text { propellant flame retardant }\end{array}$ & --- & 102 & $\begin{array}{c}\text { Greenhouse } \\
\text { Ozone depletion }\end{array}$ \\
\hline $2 \mathrm{e}$ & $\begin{array}{l}\text { Hexafluoride } \\
\text { ethone }\end{array}$ & $\begin{array}{l}\text { Industrial process (By product of } \\
\text { aluminium production) }\end{array}$ & 9,200 & 10,000 & $\begin{array}{l}\text { Ozone depletion } \\
\text { Greenhouse } \\
\text { Greenhouse }\end{array}$ \\
\hline 3 & $\begin{array}{l}\text { Nitrous } \\
\text { oxide }\end{array}$ & $\begin{array}{l}\text { fossil fuel combustion, nitrogen } \\
\text { fertilizer, industrial processes } \\
\text { (acid andnylon, applications in } \\
\text { medicine). Water shed } \\
\text { management }\end{array}$ & $265-298$ & $100-120$ & $\begin{array}{c}\text { greenhouse } \\
\text { ozone depletion }\end{array}$ \\
\hline 4 & $\begin{array}{l}\text { Tropospheri } \\
\text { c ozone }\end{array}$ & $\begin{array}{c}\text { Fossil fuel combustion, industrial } \\
\text { processes (fluorinated gases, } \\
\text { halocarbons) } \\
\text { Carbon monoxide, oxide gas, } \\
\text { oxides of nitrogen gas. } \\
\text { Photochemical reaction }\end{array}$ & $62-69$ & 20 & Greenhouse \\
\hline 5 & $\begin{array}{l}\text { Sulphur } \\
\text { Dioxide }\end{array}$ & $\begin{array}{l}\text { Industrial processes (solvent } \\
\text { extraction, pulp making). } \\
\text { Combustion of fossils fuel. } \\
\text { Biomass burning. }\end{array}$ & & & Acid rain \\
\hline & $\begin{array}{c}\text { Sulphur } \\
\text { Hexafluoride } \\
\text { (5F6) }\end{array}$ & $\begin{array}{c}\text { Production of electronic } \\
\text { components, magnesium and } \\
\text { aluminium smelters, chemical } \\
\text { companies. }\end{array}$ & 100 & 3200 & \\
\hline 6 & $\begin{array}{l}\text { Nitrogen } \\
\text { Trifluoride }\end{array}$ & $\begin{array}{l}\text { Industrial process (gas, chemical } \\
\text { and electronic companies) } \\
\text { production of solar cells. }\end{array}$ & 17,200 & $550-740$ & Greenhouse \\
\hline
\end{tabular}

Table 2 : Showing the Anthropogenic Sources and Environmental Effects Ofharmful Gases

Compiled From Various Sources

Nitrous oxide is a stable greenhouse gas along the troposphere but it usually breaks down when heated by the UV radiation in the stratosphere. This led to the formation of nitric oxides which destroys the ozone. In 2017, Nitrous oxide accounted for about 5.6 percent of all U.S greenhouse gas emissions from human activities. The average contribution of nitrous oxide to the atmosphere is now increasing at a rate of 0.2 to 0.3 percent per year. Despite its high rate of emission, it is expected to remain one the largest greenhouse gas in future (Grace 2014, Grace and Barton 2019, NOAA 2009).

Ozone depleting substances (ODS) are manufactured halocarbon chemicals. Halocarbons are man- made gases consisting of both carbon and at least one of the halogens (fluorine, chlorine, iodine, or bromine). All halocarbons are also greenhouse gases. Halocarbons with chloride or bromine are responsible for ozone depletion and a decrease in the density of ozone layer. The chemicals are safe to use in most applications because they are inert in the troposphere. However in 
thestratosphere, they are the major source of inorganic chlorine that is active in the photo dissociation (destruction)) of ozone.

Ozonedepletion consists of two related events observed since 1970s (1) a steady lowering of about 4 percent in the total amount of ozone in Earth's atmosphere (the ozone layer). (2) A much larger springtime decrease in stratosphere ozone around Earths Polar Regions.Largest Antarctic ozone hole ever recorded was over South Pole in September 2006. Ozone depletion is more in the Antarctica because the chemical and atmospheric condition of the region is very good at increasing the effectiveness of ozone destruction by reactive halogen gases - chlorine and bromine (Substance Information 2019, Editor of Encyclopedia 2019).

The harmfuleffects of these gases on human environment depend on three factors; (i) the concentration or abundance of the affected gas, (ii) how long the gas stays in the atmosphere, and (iii) how strongly a particular gasimpacted the atmosphere.

In term of concentration,the quantity of greenhouse gases had increased so extensively that the earth's temperature is now beyond the natural and normal level. In 2014, IPCC noted that the total greenhouse gases added to the natural system by man were as follows;F gases 2 percent, Nitrous oxide 6 percent, Methane 16 percent, and Carbon dioxide 65percent.Global greenhouse gas emissions by economic sector were; industry 21 percent, transportation 14 percent, buildings 6 percent, agriculture/forestry 24 percent, electricity and heat production 25 percent, and other energy sources 10 percent (Worldatlas 2019, Tian et al 2018, EPA 2019).

With regard to atmospheric lifetime, harmful natural gases spend between few days to 120 years, while those associated with man(industrial processes) spends between 102 and 50,000 years (see table II). Very long atmospheric lifetime of these gases allows for their accumulation over a very long period, and this wouldmake it difficult for man to revert the observable greenhouse effects within a short period of time. It would also allow these gases gain enough time to drift up into the stratosphere and reacted with the Ozone gas.

The strength of gases to induce greenhouse effect had been computed relative to that of carbon dioxide (see table ii).Nitrogen-trifluoride for instance is 17,200 times as strong as carbon dioxide in trapping infra-red radiation (heat).Those of other gases are indicated on table II. By implication, though these gases are available as traces in the air, their capacity to induce greenhouse effect far outweigh that of carbon dioxide. As various compounds and alloys of these gases are increasingly been released into the Atmosphere by man, the resulting greenhouse effect (increase in temperature) would be so sporadic and severe than what many biospheric organisms and natural systems can tolerate.

In term of major producing countries, China accounted for 30 percent, United States 15 percent, EU-28/9 percent, India 7 percent, Russia 5 percent, and Japan 4 percent. In Nigeria, total emissions in 2014 were 492.44 million metric tons of Carbon dioxide equivalents, totalling 1.01 percent of global GHG emissions. In Nigeria, 38.2 percent of emissions come from land use change and forestry sector (Drbogman 2019, EPA 2019).

\section{Summary and Conclusion}

The ingenuity in Man is worthy of been appreciated, particularly with respect to Atmospheric gases. Mans ability to develop the refrigeration technique assisted him to study, discover, separate, and employ Atmospheric gases for several chemical and industrial purposes. So apart from the natural biospheric attributes, atmospheric gases are reacted with other lithospheric and hydrospheric elements/chemicals by man for fuels, medicine, photography, propellants, solvents, blowing agents, chemicals, fertilizer, among others.

The proportion of these gases needed for normal atmospheric functioning vary, some in appreciable proportion (Nitrogen and Oxygen), some in minute quantity (Argon and Carbon dioxide), and the rest as traces. The overconcentration of certain minute and trace gases in the Atmosphere by man is causing global warming. Man is also reacting atmospheric gases with one another, as well as with the lithospheric and Hydrospheric chemicals. This has led to the production of powerful elements/ chemicals, the gaseous form of which had been established to have a destructive role on the ozone layer.Science has established that Global warming and Ozone depletion are responsible for the incidence of climate change.

In a bid to address the problem of climate change, 27 nations signed a global environmental treaty (The Montreal Protocol) in 1987. It was to reduce the production of substances that deplete the ozone layer.Sulphur Hexafluoride (SF6) was banned as a trace gas and its use is limited to high voltage application.Montreal protocol ban Dichlorodifluoromethane (Freon) use but allow it for use as flame retardant in air vehicles and sub marines. Nitrogen Triflouride Applicationsof chlorodifluoromethane had been phased out by the European Union and the United nations due to its ozone depletion and global warming potentials.

Because of its low concentration in the atmosphere, Tetrathuoromethane is not currently believed to have a significant radioactive forcing effect as it does not deplete the ozone. Dichlorodifluoromethane control began in 1979 with an EPA ban on Freon use as cosmetic propellants.Prior to industrialization,Hexafluoroethane (C2F6)gas did not exist in the atmosphere. Kyoto treaty of Dec 1997 was on how to restrict the emission of greenhouse gases, particularly carbon dioxide. An amendment was also approved in London in 1990 when a call was made for the elimination of CFC production by 2020. Manufacture of these chemicals/gases was however allowed in the developing countries and for some exempted applications like asthma inhalator in medicine(Edgar 181 2019, Worldatlas 2019,NOAA 2009).

\section{Suggestions}

Formation of compounds with the noble gases needs to be restricted so as not to create another set of global environmental problems for the coming generation. Technological searchlight need to be focussed on how emission of dangerous gases can be managed particularly through chemical reactions. 
More research effort is needed to ascertain the relative contribution of carbon dioxide, methane and nitrous oxide to the climate crisis. Montreal protocol dealt strongly with methane derivatives because of their industrial repute whileNitrous oxide was not regulated. Going by the observations of scholars like Tian et al2016, Grossman 2019, Grace \&Barton 2019, and Dohrman 2017, whenever nitrogen and hydrogen are used either naturally or artificially, nitrous oxide would be released. Nitrogen constitutes 78 percent by volume of the Atmosphere and plays a far reaching role on plants growth.Hydrogen is equally of industrial repute particularly as fuel. It is therefore possible that nitrous oxide would be the most abundant gas responsible for the changes observable in climate.

Breakthrough in science and technology associated with industrial revolution was boosted by the discovery and use of Atmospheric gases. And being free gifts of nature, the innovation paid off economically. Unfortunately African countries have little or no idea of these natural stocks of wealth. African nations need to float courses, purchase equipment, trained personnel's and channel research in the area of Atmospheric Chemistry, Atmospheric physics, and environmental geosciences. This is particularly so of truly inert, noble and environmentally friendly gases.

The impact of man is widespread, varies in dimension and viewed differently across regions. The industrial world understands the climate change intricacies because of its advanced culture; greater number of other cultures seems not to understand the unseen claims. Efforts must therefore be made to embark on an elaborative campaign, particularly about traditional practices which are generating unwanted gases.

Placing a ban on a region while been tolerated in other regions of the world may not yield the expected result. The world is a global village, production in one locality can easily be distributed the world over, and the pollutants generated can equally be circulated by winds and Oceans. The use of substitutes needs to be emphasised.

\section{References}

i. Air Quality Fact Sheet (2019) Nitrogen Dioxide (No2). https;//www.environment.gov.au>f...SOEST(2019) Abundance of Nitrogen in Earth's Atmosphere. Retrieved 14 November 2019, from https://www.soest.hawaii.edu/GG/ASK/atmo-nitrogen.html

ii. The Weather Prediction (2019) Air Composition: Argon. Retrieved 8 November 2019, fromhttps://www.theweather prediction.com/habyhints3/933/

iii. Encyclopaedia Britannica (2019) Biosphere - The Carbon Cycle. Https://Www.Britannica.Com >Science

iv. PRAXAIS (2019) Buy Compressed Argon Gas or Liquid Argon (Ar). Retrieved 14 November 2019, from https://www.praxair.com/gases/buy-compressed-argon-gas-or-liquid-argonWikipedia (2019) Carbon Monoxide. Https://En.M.Wikipedia.Org>Wiki

v. Periodic Table (2019) Helium - Element Information, Properties and Uses. Https://Www.Rsc.Org>PeriodictableHttps://Scince.HowstuffworksHttps://Www.Rockymountainair.Com>....

vi. _ _ (2019) Hydrogen Properties. Https://Www.Eere.Energy.Gov>Pdfs

vii. Chemistry Explained (2019) Krypton Chemical Elements. Www.Chemistryexplained.Com Chemicool (2019) Xenon.Https://Www.Chemicool.Com>XenonHttps://En.M.Wikipedia.Org>Wiki

viii. The Weather Prediction. (2019) Air Composition: Argon- Https://Www.Theweatherprediction.Com

ix. Universal Industrial Gases Inc. (2019) ... Nitrogen $\left(\mathrm{N}_{2}\right)$. www.uigi.com>nitrogen

X. Air Products and Chemicals Inc.(2019) Helium. https://www.airproducts.com.PDF ,https://en.wikipedia.org/wiki/Helium

xi. Bradford A (2016) Fact about Xenon. Livescience. https://en.m.wikiedia.org

xii. BBC News (2012) How Dangerous Is Liquid Nitrogen?Retrieved 14 November 2019, fromHttps://Www.Bbc.Com>News>Mega... https://liquidnitrogentank. com/how_cold_is_liquid_nitrogen.php

xiii. Royal Society of Chemistry (2019) Nitrogen - Element Information Properties and Uses. Www.Rsc.Org>Periodictable>Nitrogen... Retrieved 14 November 2019.

xiv. Crean B. (2018) Oxygen. https://en.m.wikipedia.org>wiki

xv. Crean B. (2018). What is the Role of Nitrogen in the Atmosphere? Https://Www.Quora .Com>What...

xvi. Blue, M. (2019). How Does Carbon Dioxide Affect the Environment? Retrieved 14 November 2019, fromhttps://sciencing.com/carbon-dioxide-affect-environment-8583965.htmlhttps://en.wikipedia. org/wiki/Carbon_dioxide

xvii. Boden TA, Marland G, Andres R.J (2017) National CO2 Emissions from fossil fuel burning, cement manufacture, and gas Flaring 1751-2014. Carbon Dioxide information Analysis centre, Oak Ridge National Laboratory, U.S. Department of Energy, Doi.

xviii. ScoltB (2018) Oxygen levels at high attitudes. Altitude Safety 101- Center for Wildness safety. https://www.worldsafe.org >resources

xix. Stevens C J, David T I, Storkey J. (2018) Atmospheric Nitrogen Deposition in Terrestrial Ecosystems: Its impact on Plant Communities and Consequences across Atrophic Level.https://doi.org/10.11/1365-2435.13063. https://cfpub.epa.gov/ncer_abstracts/index.cfm/fuseaction/display.abstractDetail/abstract/703/report/0

xx. Center For Climate and Energy Solutions (2019) Main Greenhouse Gases. Https://Www.C2 es.Org> Content $>$ Main......

xxi. Derwent R et al (2006) 'Global Environmental Impacts of the Hydrogen Economy'. International Journal of Nuclear Hydrogen Production and Applications. 1(1), PP 57-67. https://ec.europa.eu>newsalert>pdf

xxii. Dohrman, P. (2017). How Hydrogen Affect the Environment. Retrieved 14 November 2019, from https://sciencing. com/hydrogen-affect-environment-5535643.htmlhttps://eere.energy.gov/hydrogenand fuelcells/tech_validation/pdfs/fcm01r0.pdf 
xxiii. $\quad$ Drbogdan (2019) Greenhouse Gas. Https://En.M.Wikipedia.Org $>$ Wiki

xxiv. Duncan, F. (2019). Can Argon be a Solid \& Liquid? Retrieved 14 November 2019, from https://www.quora.com/Can-argon-be-a-solid-liquid

xxv. Earth System Research Laboratory (2019) Halocarbons and Others Atmospheric Trace Gases (chloroflocarbons). https://www.esrl.noaa.gov>elkins

xxvi. Edgar 181 (2019) Chlorodifluoromethane. https://en.m.wikipedia.org>wiki

xxvii. Editors of Encyclopaedia (2019) Methane; Definitions, Properties, Uses and Facts. https://www.britannica.com>science

xxviii. Editors of Encyclopaedia (2019) Ozone: Definition, Properties, Structure and Facts. https://www.britannica.com>science

xxix. Encyclopaedia Britannica (2019a) Argon | Properties, Uses, Atomic Number, \& Facts. (2019). Retrieved 8 November 2019, from https://www.britannica.com/science/argon-chemical-element

xxx. Encyclopaedia Britannica (2019c) Krypton. Retrieved 13 November 2019, from https://www.encyclopedia. com/science-and-technology/chemistry/compounds-and-elements/krypton

xxxi. Encyclopaedia Britannica (2019i) Neon | Definition, Uses, Melting Point, \& Facts. Retrieved 13 November 2019, from https://www.britannica.com/science/neon-chemical-element

xxxii. Encyclopedia Britannica (2019b) Biosphere - The carbon cycle. Retrieved 14 November 2019, from https://www.britannica.com/science/biosphere/The-carbon-cycle

xxxiii. Engineering Tool Box (2019) Air-Composition And Molecular Weight. https://www.engineeringtool box.com

xxxiv. Environmental Literacy Council (2019) Hydrogen Retrieved 14 November 2019, from https://envirolitera cy.org/energy/hydrogen/

xxxv. EPA (2019) Global Greenhouse Gas Emission Da. https://www.epa.gov>ghgemissions.

xxxvi. $\quad$ EPA (2019). What is Radon Gas? http://www.epa.gov>radiation,Https://En.M.Wikipedia.Org>Wiki

xxxvii. Papanelopoulou F (2013). The Liquefaction of Oxygen and The Emergence Of Low-Temperature Research. The Royal Society Publishing. http://Www.Ncbi.Nih.Gov>Pmc

xxxviii. Garden, H. (2019). How Helium Is Made. Retrieved 13 November 2019, from https://science.howstuff works.com/question12.htm

xxxix. Widdison G. (2017) Why Nitrogen is 78 percent in the atmosphere. https://www.soest,Hawaii. edu/aa/... https://www.quona.com

xl. Heilig G K (1994). The Greenhouse Gas Methane; Sources and Sinks, The Impact of Population Growth, Possible Interventions. Springer Vol 16, Issue 2, Page 104-137. Https://Www.Epa.Gov>Gmi.Impart......

xli. Grace, P., \& Barton, L. (2019). Meet N2O, the Greenhouse Gas 300 Times Worse Than C02. Retrieved 8 November 2019, from http://theconversation.com/meet-n2o-the-greenhouse-gas-300-times-worse-than-co2-35204

xlii. Harrison. J.A. (2019). The Nitrogen Cycle. Retrieved 13 November 2019, from https://visionlearning. com/en/library/Earth- Science/6/The-Nitrogen-Cycle/98Https://En.Wikipedia.Org>Wiki

xliii. Jack S. (2018) How Do People Get Nitrogen into Their Bodieshttps://sciencing.com/how-does-4571433-peoplenitrogen-their-bodies.html

xliv. John P. Rafferty and Melissa Petruzzela (2019) 5 Notorous Greenhouse Gases.Https://Www.Britann ica.Com>List $>5$.....Www.Thegraudinn.Com>...

xlv. Katie (2012) Krypton-Chemical.https://www.chemicool.comwww.carondelet.pvt.kiz.ca.usHttps://Www.Rsc .Org>Periodi ctable Https://www.Encyclopedia

xlvi. Lenntech B V (2019) Neon-Chemical Properties, Health and Environmental Effects. Retrieved 14 November 2019, from https://www.lenntech.com>elements https://www.lenntech.com/periodic/elements/ne.htm

xlvii. Lenntech B V (2019) Argon-Chemical Properties, Health and Environmental Effects. https://www.lenntech.com>elementsfrom https://www.lenntech.com/periodic/elements/ar.htm

xlviii. Lenntech B.V. (2019) Xenon-Chemical Properties, Health And Environmental Effects. https://www.lenntech.com>elementshttps://www.lenntech.com/periodic/elements/xe.htm

xlix. Lenntech B.V. (2019). Ozone application industrial laundries. Retrieved 8 November 2019, from https://www.lenntech.com/library/ozone/laundries/ozone-applications-laundry.htmHttps://Www.Lenntech. Com>Elements.Library

l. Pappas, S. (2019). Facts About Argon. Retrieved 13 November 2019, from https://www.livescience. com/29023argon.html

li. Lenntech B.V. (1998) Hydrogen (H) - Chemical properties, Health and Environmental Effects. Retrieved 14 November 2019, from https://www.lenntech.com/periodic/elements/h.htm

lii. Grossman L (2019) Laughing Gas is the biggest threat to Ozone Layer. New Scientist Ltd. https://www.newscientist.com

liii. Livescience (2017) Argon-Chemical Properties, Health and Environmental Effects Https://Www .Lenntech. Com>ElementsHttps://Www.Livescience.Com.2902....

liv. Nukuranjgi T (2012) Scientists Discover Abrupt Increase In $\mathrm{CO}_{2}$ Uptake By The Land Biosphere Retrieved 14 November 2019, fromhttps://niwa.co.nz/news/scientists-discover-abrupt-increase-in-co2-uptake-by-the-landbiosphere

lv. National Oceanic and Atmosphere Administration (2009) Nitrous Oxide Now Top Ozone Depleting Emission. Https://Www.Sciencedaily.Com 
lvi. Nay Lin Tech (2018) Why Is There No Hydrogen in Our Atmosphere?Retrieved 13 November 2019, fromhttps://www.quora.com/Why-is-there-no-hydrogen-in-our-atmosphere-Why-does-the-moon-have-noatmosphere

lvii. New York State Department of Health (2019). The facts about Ammonia. https://www.health.ny.govt >ammon.......

lviii. North Carolina Climate Office (2019) J Halocarbons. Https://Climate.Ncsu,Edu>Halo...

lix. Oxford (2019) Atmospheric Pressure. en.m.wikipedia.org . lite.en.m.wikipedia.org

lx. Pappas, S. (2019). Facts about Helium. Retrieved 13 November 2019, from https://www.live science. com/28552facts-about-helium.html

lxi. Periodic Table (2019) Helium - Element Information, Properties and Uses. Retrieved 13 November 2019 , from http://www.rsc.org/periodic-table/element/2/helium

lxii. Periodic Table (2019) Krypton - Element Information, Properties and Uses (2019). Retrieved 13 November 2019, from https://www.rsc.org/periodic-table/element/36/krypton

lxiii. Periodic Table (2019) Nitrogen - Element Information, Properties and Uses Retrieved 14 November 2019, from https://www.rsc.org/periodic-table/element/7/nitrogen

lxiv. Physical Geography (2019) Chapter 7: Introduction to the Atmosphere. Retrieved 8 November 2019, from http://www.physicalgeography.net/fundamentals/chapter7.html

lxv. Pidwiray M (2006) 'Atmospheric Composition'. Fundelmentals of Physical Geography, 2nd Edition. http://www.p hysicalgeography.net/fundalmentals/7a.htmc

lxvi. Plass, G. (2008). Carbon Dioxide and Climate. Retrieved 14 November 2019, from https://www.scientificamerican.com/article/carbon-dioxide-and-climate/

lxvii. Radon Repair (2019) What Are Safe Radon Levels. - Radon Abatement Services. (2019). Retrieved 14 November 2019, from https://radonrepair.com/faq/radon-levels/

lxviii. Rasmussen R.A. (1986) Atmospheric Trace Gases: Trends and Distributions Overthelast Decade. Https://En.M.Wikipedia.Org>Wiki

lxix. Roach, J. (2004). Source of Half Earth's Oxygen Gets Little Credit. Retrieved 8 November 2019, from https://www.nationalgeographic.com/news/2004/6/source-of-half-earth-s-oxygen-gets-little-credit/ Https://Www.Nationalgeographic.Com

lxx. Sarahzielinski, F. (2019). Earth's Oxygen Levels Can Affect Its Climate. Retrieved 14 November 2019, from https://www.smithsonianmag.com/science-nature/earths-oxygen-levels-can-affect-its-climate-180955572/

lxxi. Sciencing (2019) How Does Carbon Dioxide Affects the Environment. https://sciencing. com>carbon-dioxide , https://en.m.wikipedia,org

lxxii. Sciencing (2019) Uses of Methane Natural Gas. Retrieved 13 November 2019, from https://sciencing.com/usesmethane-natural-gas-6134860.html

lxxiii. Sheardown, A., Stenhouse, K., \& Donev, J. (2019). Atmospheric Oxygen - Energy Education. Retrieved 8 November 2019, from https://energyeducation.ca/encyclopedia/Atmospheric_oxygen

lxxiv. Skyrobin (2019) Hydrogen. Https://En.M,Wikipedia.Org

lxxv. Pappas S (2014) Facts about Krypton. Https://Www.Livescience.Com.

lxxvi. Gagnon S (2019) History and Uses of Hydrogen https://education.jlab.org>ele0001

lxxvii. Stewart, D. (2019). Krypton. Retrieved 14 November 2019, from https://www.chemicool. com/elements/krypton.html

lxxviii. Stewart, D. (2019). Xenon. Retrieved 14 November 2019, from https://www.chemicool. com/elements/xenon.html

lxxix. S E P A (2019) Pollutant Fact Sheet. (2019). Retrieved 14 November 2019, from http://apps.sepa.org.uk/spripa/Pages/SubstanceInformation.aspx?pid=65http://apps.sepa.org.uk/ spripa/Pages/Sub rg.uk/spripa/Pages/SubstanceInformation.aspx?pid=8

lxxx. Team, E. (2019). ESRL Global Monitoring Division - Halocarbons and other Atmospheric Trace Species. Retrieved 8 November 2019, from https://www.esrl.noaa. gov/gmd/hats /publictn/elkins/cfcs.html, https://en.m.wikipedia.org>wiki

lxxxi. Tezel, D. (2018). What is the role of Nitrogen in the Atmosphere?. Retrieved 13 November 2019, from https://www.quora.com/What-is-the-role-of-nitrogen-in-the-atmosphere

lxxxii. Environmental Literacy Council (2015) Hydrogen Https://Enviroliteracy.Org En.M.Wikipedia.Org

lxxxiii. Tian H, etal (2016). The Terrestrial Biosphere as a Net Source of Greenhouse Gases to the Atmosphere. Https://Www.Ncbi.Gov>Pub.

lxxxiv. Ucar Centre for Science Education (2007) Carbon Monoxide.. Https://Scied.Ucar. Edu>Carbonmon...

lxxxv. Union of Concerned Scientists(2019) The Ozone Hole and Global Warming.https://WWW.ucsusa.org>resources

lxxxvi. United Nations (2019) Global Warming Potentials (IPCC Second Assessment Report).http://unfccc.int>progess.global....

lxxxvii. USEPA (2017) Nitrogen Dioxide Pollution: Basic Information about $\left(\mathrm{NO}_{2}\right)$. Https://Www.Environment.Gov.Au>F.... lxxxviii. Universal Industrial Gases (2016) Oxygen Properties, Uses and Applications. Www.Uigi. Com>0xygen

lxxxix. USEPA (2019).Importance of Methane; Global Methane Initiative. Retrieved 8 November 2019, from https://www.epa. gov/gmi/importance -methaneHttps://Www.Epa. Gov>Gmi> Import.....

xc. Broecker W S (2019) Earth Oxygen Level can Attack its Climate. https://www.smithsonia mag.com 
xci. Wikidepia (2019b) Atmosphere of Earth. Retrieved 14 November 2019, fromhttps://en.wikipedia.o rg/wiki/ Atmosphere_of_Earth

xcii. Wikidepia (2019c) Atmospheric Pressure. Retrieved 14 November 2019, from https://en.wikipedia. org/wiki/Atmospheric_pressure

xciii. Wikipedia (2019g) Hydrogen. Retrieved 14 November 2019, from https://en.wikipedia. org/wiki/Hydrogen

xciv. Wikipedia (2019h) Liquid Nitrogen. Retrieved 14 November 2019, from https://en.wikipedia. org/wiki/Liquid nitrogen

xcv. Wikipedia (2019j) Nitrous Oxide. Retrieved 8 November 2019, from https://en.wikipedia. org/wiki/Nitrous_ oxide

xcvi. Wikipedia (2019k) Oxygen. Retrieved 7 November 2019, from https://en.wikipedia.org/wiki/Oxygen

xcvii. Wikipedia (2019l) Ozone. Retrieved 8 November 2019, from https://en.wikipedia.org/wiki/Ozone

xcviii. Wikipedia (2019m) Xenon. Retrieved 14 November 2019, from https://en.wikipedia.org/wiki/Xenon

xcix. Worldatlas (2019) List of Greenhouse Gases. Https://Www.Worldatlas.Com>Lis 